\title{
Genetic Variation of a $-176 g>c$ Interleukin-6 Correlated with White Blood Cells Count in Obesity of Indonesia
}

\author{
Dwi Eni Danarsih, Pramudji Hastuti ${ }^{\star}$, Agus Kristianto \\ Department of Biochemistry, Faculty of Medicine, Public Health and Nursing, Universitas Gadjah Mada, Yogyakarta, Indonesia
}

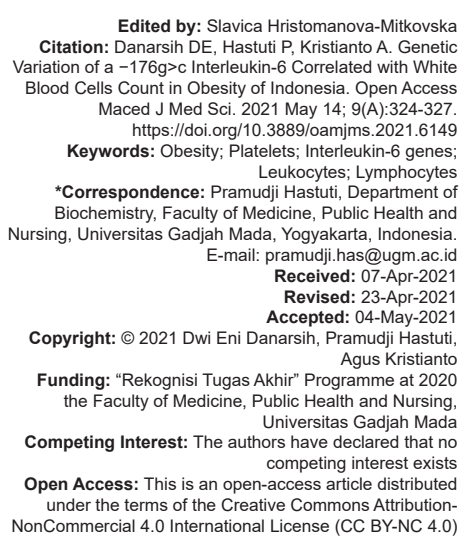

Edited by: Slavica Hristomanova-Mitkovska Edited by: Slavica Hristomanova-Mitkovska
Citation: Danarsih DE, Hastuti P, Kristianto A. Genetic Blood Cells Count in Obesity of Indonesia Open Access Maced J Med Sci. 2021 May 14; $9(\mathrm{~A}): 324-327$ https://doi. org/10.3889/oamjms.2021.6149 Keywords: Obesity; Platelets; Interleukin-6 genes; Leukocytes; Lymphocyte

*Correspondence: Pramudji Hastuti, Department of Biochemistry, Faculty of Medicine, Public Health and Nursing, Universitas Gadjah Mada, Yogyakarta, Indonesia. E-mail: pramudji.has@ugm.ac.ip Received: 07-Apr-202 Accepted: 04-May-2021
Copyright: $\odot 2021$ Dwi Eni Danarsih, Pramudji Hastuti, Agus Kristianto
Funding: "Rekognisi Tugas Akhir" Programme at 2020 the Faculty of Medicine, Public Health and Nursing Universitas Gadjah Mada Competing Interest: The authors have declared that no
competing interest exists Open Access: This is an open-access article distributed under the terms of the Creative Commons Attribution-
NonCommercial 4.0 International License (CC BY-NC 4.0)

\begin{abstract}
BACKGROUND: Obesity is a risk factor for cardiovascular disease. Obesity can trigger inflammation by increasing the synthesis of interleukin-6 (IL-6) which leads to leukocyte recruitment, differentiation of B lymphocytes, activating T lymphocyte cells, and triggering hematopoiesis. Variations in the IL-6 promoter gene are known to affect transcription rates. The previous studies have still found different results regarding the relationship between these gene variations and blood cell numbers.

AIM: This study aimed to determine the influence of IL-6 gene variation with white blood cells counts in obese people of Indonesia.

METHODS: A total of 148 people participated in this cross-sectional study. The number of obese people was 80 subjects and there were 68 non-obese people as controls. Obesity was determined based on the criteria of Asians.

RESULTS: Genotype CC was not found in this study, while the GC genotype was found only in the obese group. The GG genotype in obese group had waist circumference, diastolic blood pressure, and higher lymphocyte rates significantly higher than the non-obese group $(p<0.05)$.
\end{abstract}

CONCLUSIONS: Variation of $-174 \mathrm{G}>\mathrm{C}$ IL- 6 gene is associated with high white blood cell counts, especially lymphocytes number in obese people in Indonesia.

\section{Introduction}

The prevalence of overweight and obesity continues to increase in the world, including in Indonesia. Overweight and obesity have been associated with an increase of disability and death from cardiovascular diseases [1], [2]. Weight gain plays a role in the pathophysiology of diabetes mellitus, insulin resistance, dyslipidemia, hypertension, and atherosclerosis, due to excessive secretion of adipokines. The rise of white adipose cells can trigger the release of pro-inflammatory cytokines such as interleukin-6 (IL-6) which causes local inflammation and contributes to inflammation in all parts of the body. This inflammation ultimately causes dysfunction in some organs such as the pancreas and liver [3].

IL-6 has an important role in inflammatory, hematopoiesis, immune response, and defense mechanisms [4]. IL-6 in the bone marrow increases the maturation of megakaryocytes so that many blood cells are released into circulation [5]. In addition, IL-6 also increases hematopoiesis, including the synthesis of neutrophils, and causes the mobilization of neutrophils to the site of infection to parasitize pathogens. This cytokine induces differentiation of the T-helper 17 which serves to improve neutrophilic response [6]. Inflammation in the blood vessels and lipoproteins held in the endothelial wall is risk factors for atherosclerosis due to the formation of thrombus [7].

Variations of the -174 G>C IL-6 gene (rs1800795) are widely studied because it affects the transcription of IL-6 genes [5] so it is related to serum IL-6 levels, although there are still differences in results in some countries [8]. Research on the relationship of variations in this gene with blood cell numbers is still contradictory [9], [10]. This study aimed to determine the relationship between the $-174 \mathrm{G}>\mathrm{C}$ IL- 6 gene variation with the number of blood cells.

\section{Samples and Methods}

This cross-sectional study involved 148 subjects of Javanese ethnicity in Indonesia [11]. The study subjects were grouped into obesity and the non-obese groups. Obesity was determined from the body mass index (BMI) value calculated from the weight $(\mathrm{kg})$ divided by the squaring of the height 
$\left(\mathrm{m}^{2}\right)$. Subjects were included in the obese group if they had a BMI equal to or more than $25 \mathrm{~kg} / \mathrm{m}^{2}$ [12] and non-obese with a BMI of 18.5-24.9. The study subjects were $18-50$ years old and willing to follow the research by signing out informed consent form. Subjects taking analgesics, antipyretic, antihypertensive drugs, lipid-lowering drugs, antibiotics, and immunosuppression drugs were not included in the study. The subjects also did not have infectious diseases and cancer, nor did pregnant or nursing women. Recruitment of research subjects and sampling was approved by the Medical and Health Research Ethics Committee with the number $\mathrm{KE} / \mathrm{FK} / 0761 / \mathrm{EC} / 2018$ which was then amended by the number KE/FK/0944/EC/2019.

\section{Measurement of anthropometry, blood pressure, and hematological parameters}

The study subjects were measured for their height and weight to determine BMI, waist circumference, and blood pressure with calibrated tools. Blood samples were taken for hematological examination (leukocytes, neutrophils, lymphocytes, and platelets) and for DNA isolation. Hematological measurement used an automated hematology meter (Sysmex KX-21NR).

\section{Gene determination by polymerase} chain reaction (PCR)-restriction fragment length polymorphism

DNA samples obtained were amplified using primer (forward 5'- TGACTTCAGCTTTACTCTTGT-3' and reverse 5'-CTGATTGGAAACCTTAAG-3') with denaturation temperature of $95^{\circ} \mathrm{C}$ for $1 \mathrm{~min}$, annealing at $55^{\circ} \mathrm{C}$ for $1 \mathrm{~min}$, and primary extension at $72^{\circ} \mathrm{C}$ for $1 \mathrm{~min}$ in 30 cycles [13]. PCR products were then separated on $2 \%$ agarose gel and read with ultraviolet (UV) light (Figure 1).

PCR products were digested with Nlall enzyme at a temperature of $37^{\circ} \mathrm{C}$ for $3 \mathrm{~h}$. CC genotype was shown in fragments 122,45 , and 31 base pairs. Genotype GG is shown in fragments 167 and 31 base pairs, while GC genotype was shown by fragments $167,122,45$, and 31 [14]. The digestion products were separated in 3\% agarose gel and read under UV light (Figure 1b)

\section{Statistical analysis}

The normality of the data was tested with Kolmogorov-Smirnov. When the data were normally distributed, the independent sample t-test was used. When the data were not normally distributed, the data were analyzed with Mann-Whitney U-test.

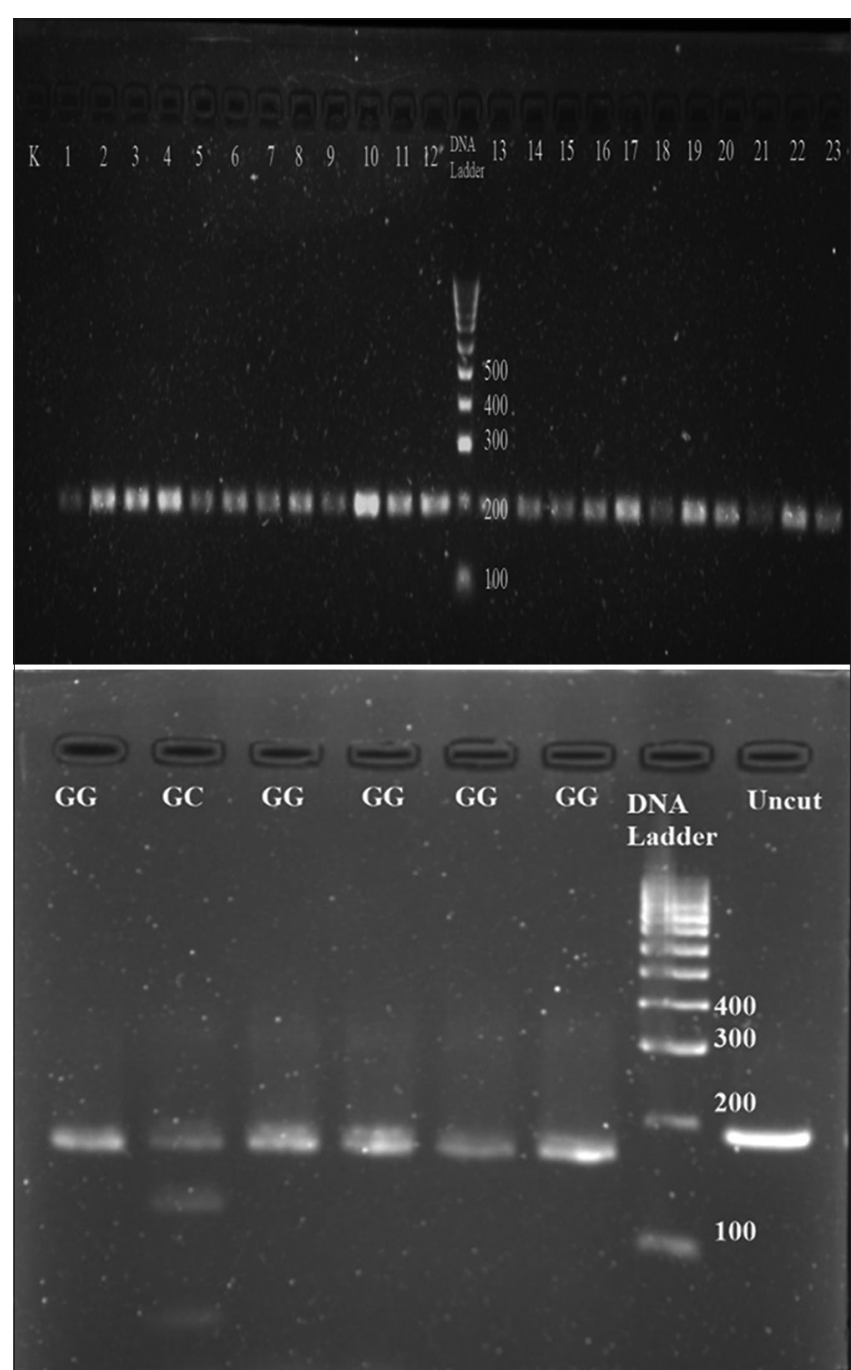

Figure 1: Polymerase chain reaction product (198 bp) of $-174 \mathrm{G}>\mathrm{C}$ IL-6 gene (rs1800795) was read under ultraviolet light after staining with FloroSafe. Electrophoresis was performed with a $2 \%$ agarose gel. DNA ladder $100 \mathrm{bp}$

\section{Results}

In this study, characteristics of subjects are shown in Table 1. There were significant differences in age, waist circumference, history of diabetes mellitus, history of hypertension, diastole blood pressure, and lymphocyte count $(p<0.05)$. The number of leukocytes, neutrophils, and platelets was higher in the obese group compared to the non-obese group, but statistically insignificant ( $p>0.05)$.

Table 1: Characteristics of subjects

\begin{tabular}{llll}
\hline Characteristic & Obese $(\mathrm{n}=80)$ & Non-obese $(\mathrm{n}=68)$ & $\mathrm{p}$-value \\
\hline Age $($ year $)$ & $43.07 \pm 10.68$ & $49.63 \pm 12.66$ & $0.001^{*}$ \\
Female $(\%)$ & $48(60)$ & $31(45.6)$ & 0.079 \\
Waist circumference $(\mathrm{cm})$ & $94.64 \pm 8.82$ & $80.22 \pm 6.81$ & $0.000^{*}$ \\
Systolic blood pressure $(\mathrm{mmHg})$ & $122.63 \pm 19.57$ & $118.09 \pm 15.57$ & 0.125 \\
Diastolic blood pressure $(\mathrm{mmHg})$ & $81.50 \pm 12.48$ & $76.98 \pm 9.47$ & $0.014^{*}$ \\
Leukocyte $\left(\times 10^{3} / \mathrm{mm}^{3}\right)$ & $7.42 \pm 1.7$ & $7.03 \pm 1.49$ & 0.154 \\
Neutrophil $\left(\times 10^{3} / \mathrm{mm}^{3}\right)$ & $5.21 \pm 5.08$ & $4.40 \pm 1.24$ & 0.202 \\
Lymphocyte $\left(\times 10^{3} / \mathrm{mm}^{3}\right)$ & $2.40 \pm 0.66$ & $2.17 \pm 0.65$ & $0.033^{*}$ \\
Thrombocyte $\left(\times 10^{3} / \mathrm{mm}^{3}\right)$ & $302.56 \pm 83.75$ & $294.72 \pm 69.46$ & 0.541 \\
\hline${ }^{*}$ Significant with Student's t-test and ${ }^{* *}$ significant with Chi-squared test with $\mathrm{p}<0.05$. &
\end{tabular}


The distribution of $-174 \mathrm{G}>\mathrm{C}$ IL- 6 genotype and allele in the obese and non-obese groups found only two people with GC genotypes in the obese group and no GC genotypes were found in the non-obese group (Table 2).

Table 2: Distribution of $-174 \mathrm{G}>\mathrm{C}$ IL-6 genotype and allele in obese and non-obese group

\begin{tabular}{llll}
\hline IL-6 gene variations & Obese $(\mathrm{n}=80)(\%)$ & Non-obese $(\mathrm{n}-68)(\%)$ & p-value \\
\hline Genotypes & & & \\
GG & $78(97.5)$ & $68(100)$ & $0.500^{*}$ \\
GC & $2(2.5)$ & 0 & \\
CC & 0 & 0 & \\
Alleles & $158(53.38)$ & $136(45.95)$ & $0.502^{*}$ \\
G & $2(0.67)$ & 0 & \\
C &
\end{tabular}

The average number of platelets, leukocytes, lymphocytes, neutrophils, age, and waist circumference in the GG and GC genotypes in the obese group did not differ significantly $(p>0.05)$ (Table 3$)$.

Table 3: Relationship of $-174 \mathrm{G}>\mathrm{C}$ IL-6 gene variation with platelet, leukocyte, and lymphocyte numbers in obese patients

\begin{tabular}{llll}
\hline Variable & Obesity & & \\
\cline { 2 - 4 } & GG $(\mathrm{n}-78)$ & $\mathrm{GC}(\mathrm{n}-2)$ & p-value \\
\hline Age (year) & $43.03 \pm 10.6$ & $44.47 \pm 19.64$ & $0.85^{*}$ \\
Waist circumference $(\mathrm{cm})$ & $94.57 \pm 8.89$ & $98.5 \pm 3.53$ & $0.53^{*}$ \\
Systolic blood pressure $(\mathrm{mmHg})$ & $122.88 \pm 19.74$ & $112.5 \pm 3.53$ & $0.45^{* *}$ \\
Diastolic blood pressure $(\mathrm{mmHg})$ & $81.54 \pm 12.54$ & $80 \pm 14.14$ & $0.90^{* *}$ \\
Leukocyte $\left(\times 10^{3} / \mathrm{mm}^{3}\right)$ & $7.39 \pm 1.74$ & $8.35 \pm 3.18$ & 0.45 \\
Neutrophil $\left(\times 10^{3} / \mathrm{mm}^{3}\right)$ & $5.19 \pm 5.14$ & $5.8 \pm 2.5$ & $0.39^{* *}$ \\
Lymphocyte $\left(\times 10^{3} / \mathrm{mm}^{3}\right)$ & $2.40 \pm 0.67$ & $2.35 \pm 0.49$ & $0.89^{* *}$ \\
Thrombocyte $\left(\times 10^{3} / \mathrm{mm}^{3}\right)$ & $300 \pm 82.49$ & $400.5 \pm 102.53$ & 0.94 \\
\hline${ }^{*}$ Significant with Student's t-test, ${ }^{* *}$ significant with Mann-Whitney U-test. &
\end{tabular}

The averages of waist circumference, diastolic blood pressure, and lymphocyte count were significantly higher in the GG genotype in the obese group than in the non-obese and statistically different $(p<0.05)$ (Table 4).

Table 4: Comparison of platelet, leukocyte, and lymphocyte count between GG genotype of -174 G>C IL-5 gene in obese and non-obese groups

\begin{tabular}{llll}
\hline Variable & GG & \\
\cline { 2 - 4 } & Obesity & Non-obe]sity & p-value \\
\hline Age (year) & $43.03 \pm 10.6$ & $49.63 \pm 12.66$ & $0.001^{*}$ \\
Waist circumference $(\mathrm{cm})$ & $94.57 \pm 8.89$ & $80.22 \pm 6.8$ & $0.000^{*}$ \\
Systolic blood pressure $(\mathrm{mmHg})$ & $122.88 \pm 19.74$ & $118.09 \pm 15.57$ & 0.176 \\
Diastolic blood pressure $(\mathrm{mmHg})$ & $81.54 \pm 12.54$ & $76.98 \pm 9.46$ & $0.012^{* *}$ \\
Leukocyte $\left(\times 10^{3} / \mathrm{mm}^{3}\right)$ & $7.39 \pm 1.74$ & $7.03 \pm 1.49$ & 0.179 \\
Neutrophil $\left(\times 10^{3} / \mathrm{mm}^{3}\right)$ & $5.19 \pm 5.14$ & $4.4 \pm 1.24$ & 0.228 \\
Lymphocyte $\left(\times 10^{3} / \mathrm{mm}^{3}\right)$ & $2.40 \pm 0.67$ & $2.17 \pm 0.65$ & $0.019^{* *}$ \\
Thrombocyte $\left(\times 10^{3} / \mathrm{mm}^{3}\right)$ & $300 \pm 82.49$ & $294.72 \pm 69.46$ & 0.67 \\
\hline${ }^{*}$ Significant with Student's t-test, ${ }^{* *}$ significant with Mann-Whitney U-test. &
\end{tabular}

\section{Discussion}

Research about polymorphism of $-174 G>C$ IL-6 gene in this study found GG and GC genotypes in the obesity group but only found GG genotype in the non-obese group. The frequency of $-174 \mathrm{G}>\mathrm{C}$ IL-6 genotype among Asian countries also gave significant results. The mutant CC genotype was not found in population studies in Malaysia but was found in Indian populations, whereas in the Chinese population, no allele C was found [16]. In line with this study, no CC genotypes were found in the ethnic Javanese population of Indonesia. GC heterozygous genotypes were found only in the obese group but only $2.5 \%$, smaller than those reported in the Malaysian (7\%) and Indian (30\%) populations. Obesity plays a role in inflammation, through the release of pro-inflammatory cytokines such as IL-6 due to increase white adipose tissue [17]. This variation of the IL-6 gene may affect the transcription of gene that affects the number of circulating IL-6 [18].

In the obese group, blood pressure and lymphocyte count in GG genotypes were higher than those of the GC genotype. For the average waist circumference, leukocytes, neutrophil, and platelet count were higher in the GC group. However, the results found no significant difference in the statistical analysis. The results of this study correspond to the study of Ma et al. [19] that found the -174 G>C IL-6 gene variation is not associated with hypertension. The IL-6 gene variation was found to be associated with hypertension in SNP $-572 \mathrm{C}>\mathrm{G}$ in the Asian population. Byrne et al. [9] obtained similar results to this study which is that there is no link between $-174 \mathrm{G}>\mathrm{C}$ IL-6 gene variation and white blood cell count. However, Fernandez-Real et al. [20] showed conflicting results. The platelet count in C allele $-174 \mathrm{G}>\mathrm{C}$ IL-6 gene was lower than that of allele G.

Genotype of GG in the obesity group was $97.5 \%$ while in the non-obese group, it was $100 \%$. Comparing the GG genotype in the obese and non-obese groups, there were significant differences $(p<0.05)$ in age, waist circumference, diastolic blood pressure, and lymphocyte numbers. Fat distribution in the abdomen is measured using waist circumference [21]. Central obesity is a risk factor for atherosclerosis by various mechanisms, one of which is through inflammation [3]. Obesity is the result of an imbalance between energy consumption and the amount of energy intake. This IL-6 cytokine increases energy use through increased heart rate, norepinephrine levels, and sympathetic nervous system stimulation [22].

Diastolic blood pressure and lymphocyte count in this study were higher in the GG genotype with obesity than non-obese. IL-6 secreted adipose tissue in obese individuals has many roles that increase the level of acute-phase protein in the liver, induce the growth and differentiation of B lymphocyte cells, activate T-system lymphocyte cells, trigger hematopoiesis, differentiate macrophages and dendritic cells, recruit leukocytes, improve neutrophil response, increase megakaryocyte maturation, and trigger platelet release [4], [5], [6]. Continuous chronic inflammation in obesity increases the concentration of IL- 6 cytokines, triggering increased production of C-reactive protein (CRP) by the liver. Increased CRP triggers decreased vasodilation and increases vascular damage. In addition, IL-6 activates STAT signaling pathways that can increase NADPH oxidase and eNOS with nitric oxide decrease and vascular superoxide enhancement. This leads to increased vascular permeability, immune cell recruitment, and endothelial dysfunction [23]. Serum 
IL-6 is known to be higher in GG genotypes than CC genotypes. GG genotype is associated with increased transcription of IL- 6 genes and the mRNA IL-6 level in vitro [17]. Obesity and IL-6 play a role in inflammation so that the presence of both variables is related to waist circumference, blood pressure, and lymphocyte numbers. Platelet numbers in the GG genotype with obesity are higher than non-obese, but statistically were not different significantly. One limitation of this study is the small number of samples prevents concluding the direct or indirect relationship of obesity with the number of cells in the blood count as a marker of inflammation.

\section{Conclusions}

This research concluded that variations in the $-174 \mathrm{G}>\mathrm{C}$ IL-6 gene in the Javanese population found in the GG genotype in obesity are associated with higher diastolic blood pressure and lymphocyte count. This research needs to be continued by examining other genotypes that may affect inflammation due to obesity with a larger number of samples.

\section{References}

1. Hruby A, Hu FB. The epidemiology of obesity: A big picture. Pharmacoeconomics. 2015;33(7):673-89.

PMid:25471927

2. World Health Organization. Obesity and Overweight; 2020. Available from: https://www.who.int/news-room/fact-sheets/ detail/obesity-and-overweight. [Last accessed on $2021 \mathrm{Mar}$ 23].

3. Redinger RN. The pathophysiology of obesity and its clinical manifestations. Gastroenterol Hepatol (N Y). 2007;3(11):856-63. PMid:21960798

4. Hoene $M$, Weigert $C$. The role of interleukin- 6 in insulin resistance, body fat distribution and energy balance. Obes Rev. 2008;9(1):20-9.

PMid: 17956545

5. Tanaka T, Narazaki M, Kishimoto T. IL-6 in Inflammation, immunity, and disease. Cold Spring Harb Perspect Biol. 2014;6(10):a016295. https://doi.org/10.1101/cshperspect.a016295

PMid:25190079

6. Parham P. The Immune System. New York: Garland Science; 2015.

7. Arman M, Payne $\mathrm{H}$, Ponomaryov $\mathrm{T}$, dan Brill A. Role of platelets in inflammation. In: The Non-Thrombotic Role of Platelets in Health and Disease. 2015. p. 37-40. https://doi. org/10.5772/60536

8. Nadeem A, Naveed AK, Hussain MM, Aslam M, Siddiqui A, Saeed SA. Variations in association of interleukin 6-G174C single nucleotide polymorphism with Type 2 diabetes mellitus-a review. Int J Diabetes Dev Ctries. 2013;33(4):186-91. https:// doi.org/10.1007/s13410-013-0147-x
9. Byrne CE, Fitzgerald A, Cannon CP, Fitzgerald DJ, Shields DC. Elevated white cell count in acute coronary syndromes: Relationship to variants in inflammatory and thrombotic genes. BMC Med Genet. 2004;5:13. https://doi. org/10.1186/1471-2350-5-13

PMid: 15171792

10. Danielsson P, Truedsson L, Eriksson KF, Norgren L. Inflammatory markers and IL-6 polymorphism in peripheral arterial disease with and without diabetes mellitus. Vasc Med. 2005;10(3):191-8. https://doi.org/10.1191/1358863x05vm617oa

PMid:16235772

11. Puspasari A, Maharani C, Mus R, Setyawati I, Hastuti P. Higher circulating white blood cell and lymphocyte counts in obese metabolic syndrome patients: A preliminary population-based study in Yogyakarta, Indonesia. Malays J Med Health Sci. 2020;16(4):34-9.

12. Kurniati N. Obesity and central obesity. Med J Indones. 2018;27(2):114-20.

13. Hastuti $P$, Martantiningtyas DC, Karita D, Tasmini T, Sadewa AH. Association of-174 G>C interleukin-6 gene polymorphism with interleukin- 6 and C-reactive protein levels and obesity: A casecontrol study among people/residents of western Indonesia. Med J Malaysia. 2019;74(5):400-4.

PMid:31649216

14. Shehab MJ, Abdul-Hassan IA. The association of interleukin-6 gene polymorphism at -174G>C SNP in Iraqi patients with Type 2 diabetes mellitus. Elixir Int J. 2015;88:36372-6.

15. World Health Organization Western Pacific Region. The AsiaPacific Perspective: Redefining Obesity and its Treatment; 2000. Available from: https://www.apps.who.int/iris/bitstream/ handle/10665/206936/0957708211_eng.pdf. [Last accessed on 2021 Mar 25].

16. Gan GG, Subramaniam R, Nadarajan VS. Ethnic variation in interleukin-6-174 (G/C) polymorphism in the Malaysian population. Balkan J Med Genet. 2013;16(2):53-8. https://doi. org/10.2478/bjmg-2013-0032

17. Coelho M, Oliveira T, Fernandes R. Biochemistry of adipose tissue: An endocrine organ. Arch Med Sci. 2013;9(2):191-200. PMid:23671428

18. Nadeem A, Naveed A, Hussain MM, Aslam M, Siddqul A Saeed SA. Variations in association of interleukin 6-G174C single nucleotide polymorphism with Type 2 diabetes mellitus: A review. Int J Diabetes Dev Ctries. 2013;33(4):186-91. https:// doi.org/10.1007/s13410-013-0147-x

19. Ma H, Sun G, Wang W, Zhou Y, Liu D, Tong Y, et al. Association between interleukin-6-572 $\mathrm{C}>\mathrm{G}$ and $-174 \mathrm{G}>\mathrm{C}$ polymorphisms and hypertension. Medicine. 2016;95(2):1-15.

20. Fernandez-Real J, Vendrell J, Richart C, Gutierrez C Ricart W. Platelet count and Interleukin 6 gene polymorphism in healthy subjects. BMC Med Genet. 2001;2:6. https://doi. org/10.1186/1471-2350-2-6 PMid:11397324

21. Kurniati N. Obesity and central obesity. Med J Indones 2018;27(2):69-70.

22. Popko K, Gorska E, Demkow U. Influence of Interleukin-6 and G174c polymorphism in II-6 gene on obesity and energy balance. Eur J Med Res. 2010;15 Suppl 2:123-7. https://doi. org/10.1186/2047-783x-15-s2-123 PMid:21147639

23. Tanase MD, Gosav EM, Radu S, Ouatu A, Rezus C, Ciociou M, et al. Arterial hypertension and interleukins: Potential therapeutic target or future diagnostic marker? Int J Hypertens. 2019;2019:3159283. https://doi.org/10.1155/2019/3159283

PMid:31186952 